\title{
Austerity in Civil Procedure
}

\author{
A Critical Assessment of the Impact of Global Economic Downturn on Civil Justice in Ghana
}

Ernest Owusu-Dapaa \& Ebenezer Adjei Bediako*

\begin{abstract}
The demand for and availability of civil justice procedures for small claims can neither be disentangled nor extricated from the health of the economic climate of the relevant country concerned. In this article, it is argued that despite not being a developed country, Ghana was not completely insulated from the hardships or implementation of austerity measures that were triggered by the global economic meltdown. The inevitability of behavioural changes on the part of the Government of Ghana as lawmaker and provider of the machinery for civil justice on the one hand and small claims litigants as users of the civil procedure on the other hand are also explored in the article. After properly situating the exploration in the relevant economic context, the article makes recommendations regarding how to minimise the impact of the austerity measures on small claims litigants.
\end{abstract}

Keywords: austerity, small claims, civil justice, civil procedure, Ghana civil procedure

\section{Introduction}

The burden of this article is to explore the issue of austerity in civil procedure and its impact on small claims from the perspective of Ghana's civil justice system in the wake of the economic downturn that affected many countries in the world. In the context of this article, small claims refer to civil cases that are triable by the District Courts in Ghana. In effect, cases or claims that do not exceed twenty thousand Ghana cedis (GHc20,000) may be classified as small claims. This is because the District Courts in Ghana do not have jurisdiction in cases where the amount being claimed exceeds GHe20,000.00. ${ }^{1}$ Small claims were not insulated from the recent economic crunch around the globe. The present exploration will be illuminated by an appreciation of the extent of the economic crunch in its relation to settlement of small claims.

* Ernest Owusu-Dapaa is Lecturer in Law at the Kwame Nkrumah University of Science and Technology, Kumasi, Ghana. Email: eodapaa@yahoo.com. Ebenezer Adjei Bediako is Principal Research Assistant at the Kwame Nkrumah University of Science and Technology, Kumasi, Ghana.

1. Section 47(1)(a) of the Courts Act, 1993 (Act 459) as amended by the Courts (Amendment) Regulations, 2014 (LI 2211).
The global economy until recently was set on the path of contraction and lack of growth. The World Bank in its Global Monitoring Report 2009 vividly portrayed the economic situation of the world as follows:

[e]merging and developing countries are increasingly affected by the recession in advanced economies through trade and financial market channels; earlier expectations that these countries would be able to 'decouple' and weather the storm through rising domestic demand have turned out to be overly optimistic. With contracting world trade, slowing domestic demand, and sharply reduced access to external financing, emerging market growth is expected to decline sharply to 1.5 percent in 2009 , from 6.1 percent in 2008, which would be the weakest growth rate since the 1990s. In general, low income countries have been less affected by the financial contagion, but slowing exports and deteriorating terms of trade for commodity exporters will increasingly hit growth prospects in 2009: growth in Sub-Saharan Africa, for instance, will drop to 1.7 percent, from 5.5 percent in $2008 .^{2}$

The global recession and its attendant austerity measures by governments in order to ensure fiscal discipline affected many economies in various ways. Although developing countries generally record continuous phenomenal growth in their economies, the global economic meltdown affected developing countries like Ghana adversely. It is also important to note as Naude has observed that '[a]lthough developing countries will be affected in the form of lower growth, higher unemployment and poverty, and changes in inequality,[...] there are many and various channels for the impact to affect countries differently, depending on the extent to which they are vulnerable to particular channels'. ${ }^{3}$

The economy of Ghana like many developing countries depends heavily upon donor aid and other forms of economic assistance. Consequently, contraction in economies of developed countries and its associated austerity measures would significantly reduce the amount of

2. World Bank, Global Monitoring Report 2009, at 24-5, at <http:// siteresources.worldbank.org/INTGLOMONREP2009/Resources/ 5924349-1239742507025/GMR09_ch01.pdf> (last visited 5 June 2015).

3. W. Naude, 'The Financial Crisis of 2008 and the Developing Countries', Discussion Paper No. 2009/01UNU World Institute for Development Economics Research (UNU-WIDER) Katajanokanlaituri 6 B, $00160 \mathrm{Hel}-$ sinki, Finland. 
donor funds that may be available to Ghana as a developing country. Since a developing country like Ghana relies on the generosity of donor countries and multinational donor agencies to finance significant aspects of their annual budgets, any major squeeze in the economic output of these donor countries will profoundly affect the quantum of aid that will be available to Ghana. What is further worrying is that when there is contraction of the economies of donor countries, it is not only the direct aid or grant that will suffer severe cut or freeze but also indirect economic assistance and foreign direct investment from such countries may be downsized.

Indeed, the World Bank in its 2009 report, aforementioned, noted that ' $[\mathrm{b}] \mathrm{anks}$ and investors in advanced economies have sharply reduced their exposure to emerging markets and developing countries'. 4 A joint report by the Organization for Economic Co-operation and Development (OECD) and World Trade Organization (WTO) in the same 2009 made a similar observation that:

[s]ince the end of 2008, developing countries have begun to feel the full effects of the financial and economic crises. Initially, banks and other financial institutions in most developing countries seemed to have been shielded from the financial crises due to their limited exposure to the financial instruments that lay at its core. Since then, however, it has become clear that their domestic capital markets and their access to international capital markets are being affected directly and significantly. Investors in developed countries have pulled resources back from emerging markets and other developing countries, in part because of the de-leveraging process of their financial institutions. $^{5}$

Thus, Ghana's economy like other vulnerable developing and emerging economies suffered its fair share of donor fatigue and its attendant chain reaction for the economy including withdrawal of government subsidies on essential commodities and services, retrenchment, and suspension of infrastructural projects. Those consequences meant that despite being developing or emerging economy (or perhaps middle-income country), Ghana's economy was in contraction mode during the period of the recession in the advanced economies of the world.

The dependence of developing countries including Ghana on advanced economies is so profound that even if there are positive signals of economic improvement in the domestic fiscal regime, a lot of caution will still need to be exercised in any analysis or forecast. This need for caution was amply demonstrated in the budget speech of Ghana's Finance Minister when he echoed:

4. Ibid., 27

5. OECD and WTO, Aid for Trade at a Glance 2009: Maintaining Momentum, at $22<$ www.oecd.org/dac/aft/43234753.pdf> (last visited 1 August 2015).
Madam Speaker, in Sub-Saharan Africa, economic recovery has been faster than expected with projected growth rate of 4.5 percent in 2010 and 5.7 percent in 2011 compared with the growth rate of 2.0 percent in 2009. The downside risks to this favourable growth outlook are the highly volatile financial sector and the uncertainties in the developed countries which can result in lower demand for ram materials, and lead to lowering of commodity prices. ${ }^{6}$

It follows from the foregoing that while it may be accurate to contend that the global financial crisis was a discernible phenomenon in the developed economies, it would be palpably misleading if the reverberations of the economic meltdown of developed countries were ignored. In this regard it is apposite to explore whether the crisis in the developed countries necessitated adoption of some sort of austerity measures that could affect civil justice in particular small claims.

Undoubtedly, there exists a close relationship between economic circumstances of a country and its civil justice system. Such a relationship could even be regarded as symbiotic in the sense that the economy of a country contributes towards effective civil justice system and vice versa. ${ }^{7}$ The substantive norms of a civil justice system as well as its institutional and procedural aspects can all be affected adversely should there be major economic downturn as was experienced across the globe not too long ago.

A vibrant economy will generate business disputes that warrant an efficient and reliable civil procedure system for the resolution of such disputes. The extent to which civil justice system has been affected by austerity measures adopted in the wake of the global economic crunch is a theme that cannot be left unexplored. The present subject is completely unexplored in relation to Ghana. It is instructive to observe that as far back as 2012, Greenberg and McGovern conducted a study on the subject in relation to the United States. In their seminal preliminary empirical studies entitled An Early Assessment of the Civil Fustice System After the Financial Crisis-Something Wicked This Way Comes?, the authors remarked that:

preliminary assessment of the impact of the financial crisis on various facets of the civil justice system identified five significantly affected areas that warrant further empirical research and additional data collection: (1) state judicial branch resourcing, (2) patterns of litigation, (3) securities litigation and enforcement, (4) trends in the legal services industry, and (5) legal

6. K. Duffour, 'The 2010 Budget Statement and Economic Policies of the Government', para. 26. <www.mofep.gov.gh/sites/default/files/budget /2011_Budget.pdf> (last visited 20 July 2015) (emphasis added).

7. See D. Weisbrot, 'Reform of the Civil Justice System and Economic Growth: Australian Experience' <www.alrc.gov.au/news-media/2000/ reform-civil-justice-system-and-economic-growth-australianexperience> (last visited 19 November 2015); G.P. Hoetker and T. Ginsburg, 'The Unreluctant Litigant? An Empirical Analysis of Japan's Turn to Litigation' (September 8, 2004), U Illinois Law \& Economics Research Paper No. LE04-009, available at SSRN: <http://dx.doi.org/ 10.2139/ssrn.608582> 
aid and the provision of legal services. Specifically, state court systems have experienced increased stress and funding restrictions. ${ }^{8}$

Drawing upon the remarks by Greenberg and McGovern in their seminal study on the subject aforementioned, the article will first provide an overview of the institutional and social context of civil justice in Ghana. It proceeds to present an overview of civil procedure and small claims in Ghana and finally undertakes a surgical analysis of the impact of the financial crisis on civil justice for small claims. Before the article concludes, recommendations are made regarding how users of small claims procedure in the civil justice system can have their interests better safeguarded.

\section{Institutional and Sociological Background of Civil Justice in Ghana}

A more informed appreciation of the impact of the financial crisis on small claims civil procedure in Ghana will require some insights into the institutional dimension of civil justice in the relevant jurisdiction under consideration. Ghana's legal system belongs to the common law tradition due to her colonial legacy from Great Britain. ${ }^{9}$ Consequently, civil procedure in Ghana shares most of the characteristics of the common law family with slight adaptations that suit the local circumstances of the Ghanaian society. ${ }^{10}$

\subsection{Adversarial Nature of Civil Procedure in Ghana}

Civil procedure or litigation in Ghana is purely adversarial in character. This refers to how cases are adjudicated upon and can be distinguished from the inquisitorial system that is frequently found within the continental legal tradition. The adversarial approach is where adjudication is seen as a contest between two or more sides and that is fought out before a neutral umpire. The judge as an umpire may ask questions for clarity but should not become an investigator. The judge should rather concentrate on ensuring that both parties are obeying the procedural rules governing the presentation of their case. ${ }^{11}$

A central plank of the adversarial process in Ghana is the fact that the parties, not the court, call witnesses. Thus, the plaintiff (or petitioner) and the defendant (or respondent) will gather their evidence, including asking witnesses to give testimonies. It follows the evidential maxim that ei incumbit probatio qui dicit, non qui negat (the burden of proof is on he who declares, not on he who denies). ${ }^{12}$ This principle is statutorily enshrined as: '[e]xcept as otherwise provided by law, unless and until it is shifted a party has the burden of persuasion as to each fact the existence or non-existence of which is essential to the claim or defence he is asserting'. ${ }^{13}$

In a long line of cases, the courts have emphasised that a party who makes an assertion but fails to adduce the requisite evidence in proof of that assertion may have an adverse finding on that allegation being made against him or her. ${ }^{14}$ Despite the evidential burden placed upon a proponent of a fact, the court still has a statutory discretion to exclude relevant evidence if the probative value of the evidence is substantially outweighed by

a. considerations of undue delay, waste of time, or needless presentation of cumulative evidence; or

b. the risk that admission of the evidence will create substantial danger of unfair prejudice or substantial danger of confusing the issues; or

c. the risk, in a civil action, where a stay is not possible or appropriate, that admission of the evidence will unfairly surprise a party who has not had reasonable ground to anticipate that such evidence would be offered. $^{15}$

Also 'evidence that would be inadmissible if objected to by a party may be excluded by the court on its own motion'. ${ }^{16}$

It appears from the provisions above that a judge may play active role in the admissibility of evidence from parties in order to ensure fairness in the trial. This is in consonance with the underlying philosophy of civil justice system in Ghana as embodied in the High Court (Civil Procedure) Rules, 2004 (C.I. 47). This philosophy is:

These Rules of Court shall be interpreted and applied so as to achieve speedy and effective justice, avoid delays and unnecessary expense, and ensure that as far as possible, all matters in dispute between parties may be completely, effectively and finally determined and multiplicity of proceedings concerning any of such matters avoided. ${ }^{17}$

The adversarial character of Ghana's civil justice system is still further tempered by the fact that, where a judge considers it necessary or needs further clarification of any piece of evidence, he or she may interrogate a witness. This is however seldomly done.

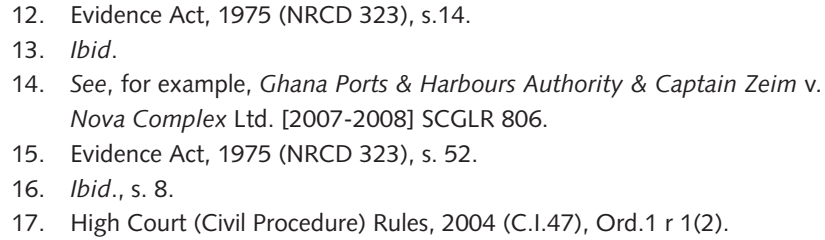




\subsection{Adherence to the Doctrine of Judicial Precedent}

Another poignant feature of Ghana's legal system is that the courts follow the doctrine of judicial precedent. This doctrine also known as stare decisis. By this doctrine, judges are required to follow previously decided cases when cases of similar facts or cases involving similar questions of law are presented before them. It is noteworthy that it is only the decisions of the Supreme Court,${ }^{18}$ Court of Appeal, ${ }^{19}$ and the High Court, being the superior courts of judicature that can constitute binding precedents in appropriate circumstances. The Supreme Court usually follows its own previous decisions except where it considers it necessary to make a departure. By the above doctrine, every decision of a higher court is binding on a lower in the court structure of Ghana.

2.3 Legal Representation in the Courts of Ghana Legal representation in civil proceedings is not mandatory in Ghana especially at the lower courts. ${ }^{20}$ Thus, for simple claims it is not uncommon to see litigants pursuing or prosecuting their own claims in the District and Circuit Courts. ${ }^{21}$ Although it is not mandatory to engage the services of a lawyer before one can pursue a claim in the High Court, ${ }^{22}$ the rules of court are complicated for a lay litigant to appear without a lawyer. With regard to body corporates however, the law requires that they must prosecute their cases by a lawyer. ${ }^{23}$ There are no official statistics regarding the number of cases that litigants prosecute their claims through the services of a lawyer or the number of cases that litigants prosecute their cases without the services of a lawyer. Be that as it may, it can be reasonably inferred from reported cases that about seventy percent of litigants use the services of lawyers to prosecute their cases in court.

\subsection{The Ghanaian District Court System}

The civil justice system in Ghana is served by a wellstructured court system and highly skilled personnel. As noted earlier, small claims are handled by the District Courts. Thus, there are District Courts in every district or sub-metropolitan or sub-municipality in Ghana. The District Courts are presided over by a magistrate who may be a lay career magistrate or a lawyer who is appointed as a magistrate. The lay magistrate pro-

18. Under Art. 129(3) of the 1992 Constitutions and section 2(3) of the Courts Act, 1993 (Act 459) as amended 'all other courts shall be bound to follow the decisions of the Supreme Court on questions of law'.

19. In terms of Art. 136 (5) of the Constitution above and section 10(5) of the Courts Act, above, 'all courts lower than the Court of Appeal shall follow the decisions of the Court of Appeal on questions of law'.

20. The Lower courts of Ghana are the Circuit Courts, District Magistrate Courts, and tribunals including the Judicial Committees of the Houses of Chiefs.

21. In terms of order 3 rule 1(5) of the Dictrict Court Rules, 2009 (C.I. 59), a litigant can either orally or in writing, request the Registrar of the District to issue a writ for him or her.

22. Under order 4 rule 1(1) of the High Court (Civil Procedure) Rules, 2004 (Cl 47), 'any person may begin and carry on proceedings in person or by a lawyer'.

23. Please see order 4 rule 1 (2). Further, 'a next friend or guardian ad litem of a person with disability shall act by a lawyer'. gramme was reintroduced in 2003 when there were as many as fifty-eight District Courts that had no presiding magistrates. ${ }^{24}$ The situation arose because conditions of service were not attractive to most lawyers. ${ }^{25}$ Any layperson ${ }^{26}$ with first degree in any field could undergo a two-year intensive training programme to become a lay career magistrate. ${ }^{27}$ According to the Judicial Training Institute of Ghana, the objectives of training tailored for prospective lay career magistrates are twofold, namely:

1. [t]o prepare career magistrates to perform their judicial and administrative functions effectively and with confidence.

2. [t]o acquire knowledge in the practical aspects of the law, procedure, and evidence required by career magistrates to try cases competently as well as administer courts efficiently and effectively. ${ }^{28}$

One major advantage of the lay magistrate programme is that it reinforces the objective of relaxing rules of procedure and legal technicalities in the adjudication of small claims as we argue later. Users of District Courts are predominantly very simple people and often with little or no education so toning down strict rules of procedure is quite a reasonable arrangement. ${ }^{29}$ Nevertheless, there is a propensity for perception of corruption that mares the beauty of the career magistrate concept. This is particularly so since lay magistrates cannot rise through the ranks to be justices of the superior courts unlike their counterpart lawyer-magistrates.

Statistics on the volume and frequency of cases that go through the court system are not generated with regularity in Ghana. However, a survey of cases from one of the judicial regions can be used to estimate the volume of small claims litigation in Ghana. Informal data gathered from the Greater Accra region suggests that there were over 7700 small claims that were recorded in the registry of the District, Circuit, and High Courts in that

24. Ghana News Agency, 'Law School to train Career Magistrates', <www. ghanaweb.com/GhanaHomePage/NewsArchive/Law-School-to-trainCareer-Magistrates-41093> (last visited 27 July 2015).

25. Ibid.

26. Layperson in the context of this means any person who has not had formal legal training.

27. The Courts (Amendment) Act, 2004 (Act 674) states that: 'The Courts Act 1993 (Act 459) as amended is further amended as follows (a) in section 46 , by the substitution for subsection (I) of the following. Qualification of a Magistrate and sitting of the District Court (46.1) A person does not qualify to be appointed a magistrate of a District Court unless the person is of high moral character and proven integrity and

(i) is a lawyer, or

(ii) is a person with such judicial or legal knowledge as the Chief Justice shall on the advice of the Judicial Council determine.'

28. Judicial Training Institute, 'Career Magistrate Induction Course', <www. jtighana.org/news.php?id=1\&event_name=Career+Magistrate +Induction+Course $>$ (last visited 1 August 2015).

29. In this regard, order 1 rule 1 (2) (a) and (b) provides that the District Court rules, like that of the High Court rules, are 'to be interpreted and applied in a manner that helps to (a) achieve speedy and effective justice, (b) avoid delays and unnecessary expense...'. 
region during the $2012 / 2013$ legal year. ${ }^{30}$ Around the same period, there were over $56518^{31}$ matters recorded in District Courts registry across the entire country. These claims included debt recoveries, landlord and tenant relations, personal injuries, matrimonial causes, adoption and child maintenance, etc. ${ }^{32}$

\subsection{Financial Jurisdiction of the Courts in Ghana}

Civil litigation is expensive and continues to be expensive due to unofficial expenses that litigants have to pay. In order to have a better understanding of the potential cost of litigation in Ghana, it is necessary to first consider the quantum of financial jurisdiction of courts in Ghana. Small claims are mainly dealt with by the District Court. The District Court, which is the lowest in the court structure of Ghana, has jurisdiction over contracts and tort actions and recovery of liquidated sum not exceeding twenty thousand Ghana cedis $(\mathrm{GH} \notin 20,000) .{ }^{33} \mathrm{~A}$ civil litigation in a District Magistrate Court will cost a litigant in the first instance about three thousand Ghana cedis (GHc3000) which is the equivalent of 1200 US dollars. ${ }^{34}$ This cost comprises statutory filing fees and unofficial payments that have to be made to private bailiffs and other court officials.

The Circuit Court has jurisdiction over many matters including contracts, tort actions and recovery of liquidated sum not exceeding fifty thousand Ghana cedis $(\mathrm{GH} c 50,000),{ }^{35}$ and actions involving occupation, possession and title to land, landlord, and tenant cases. ${ }^{36}$

214 The cost of litigating any of these matters in the circuit court could range from five thousand Ghana cedis (GH 45000$)$ to anything over ten thousand Ghana cedis (GHc10,000). The High Court, on the other hand, has jurisdiction in 'all matters'. ${ }^{37}$ Indeed, apart from the original jurisdiction of the Supreme Court of Ghana regarding the interpretation and enforcement of the Constitution, ${ }^{38}$ the High Court has original jurisdiction in all cases both civil and criminal.

In determining the jurisdiction of the court to hear a matter, the court usually pays regard to the claim but not the defence. Accordingly, a defendant is not ordinarily to oust jurisdiction of the court, but where it is difficult to determine the nature of the plaintiff's claim, the

30. Personal communication with a Senior Court official, name withheld upon request.

31. <http://judicial.gov.gh/index.php/judicial-statistics> (last visited 15 July 2015).

32. Ibid.

33. Section 42(1)(a)(1) of the Courts Act, 1993 (Act 459) as amended by the Courts (Amendment) Regulations, 2014 (LI 2211)

34. S.A. Brobbey, Practice and Procedure in the Trial Courts \& Tribunals of Ghana (2nd edn) (2011).

35. Section 47(1)(a) of the Courts Act, 1993 (Act 459) as amended by the Courts (Amendment) Regulations, 2014 (LI 2211).

36. Courts Act, 1993 (Act 457) as amended, ss. 40-42

37. Art. 140(1) of the 1992 Constitution and section 15(1) of the Courts Act, ibid.

38. Art. 2(1) of th 1992 Constitution court will pay regard to the issues that emerge between the parties not the wording of the plaint. ${ }^{39}$

\subsection{Expensive Nature of Litigation in Ghana}

Litigation in the High Court is relatively expensive. As stated earlier, pursuing a basic claim in the High Court could cost a litigant not less than ten thousand Ghana cedis. There are various kinds of costs that litigants in Ghana have to settle. First, parties have to meet the statutorily prescribed filing fees. The quantum of the fees depends upon the nature and value of the subject matter of the claim and also the nature of court processes that the parties been filed. ${ }^{40}$ Second, a litigant may have to pay for legal representation. The Ghana Bar Association's Scale of Fees usually guides lawyers on the specific amounts that they may charge for their legal representation. This Scale of Fees is however not binding. As a result, legal fees that lawyers charge are usually not uniform. To this end, it is not uncommon to find some lawyers charging above the prescribed fees. It is worthy to note that virtually all lawyers in Ghana are members of the GBA. Moreover, a party to a litigation may have to bear the costs ordered by the court to be paid to his or her opponent due to many possible reasons including non-attendance of court proceedings, defeated applications, or losing of case on the merits.

\subsection{Legal Aid Scheme in Ghana}

Ghana has a legal aid scheme that has been established with the aim to extending legal and related services to persons who have a cause of action but lack the well withal to prosecute them. The scheme was established under the Legal Aid Scheme Act. ${ }^{41}$ The scheme provides legal aid to minimum wage earners who might desire legal representation in civil matters relating to landlord and tenant, insurance, inheritance with particular reference to the Intestate Succession Act, ${ }^{42}$ maintenance of children, and such other civil matters as Parliament may from time to time prescribe ${ }^{43}$ and any person who in the view of the Legal Aid Board requires legal aid. ${ }^{44}$ Legal practitioners selected for participation by the Board of the Legal Aid Scheme provide legal services to the persons who qualify under the Scheme on pro bono basis. Apart from individual practitioners selected by the Scheme, there are non-governmental organisations (NGO) and non-profit-making organisations that are fully dedicated to providing legal aid services with government and donor funds. ${ }^{45}$

The services provided to beneficiaries of the Scheme include representation by a lawyer, all assistance that

Akarti v. Nartey [1980] GLR 218; Amponsah v. Amponsah [1997-98] 1GLR 43.

40. The fees payable for court processes are spelt out in the Civil Proceedings (Fees and Allowances) (Amendment) Rules, 2014 (C.I. 86).

41. Legal Aid Scheme Act 1997 (Act 542).

42. Intestate Succession Act 1985 (PNDCL 111).

43. Constitution 1992, Art. 294 (1); Legal Aid Scheme Act 1997 (Act 542), s. 2(2)(a)(i).

44. Legal Aid Scheme Act 1997 (Act 542), s. 2(2)b.

45. Typical examples of NGOs providing legal aid include the Legal Resources Centre, Centre for Human Rights and Advanced Legal Research, an Federation of Women Lawyers (Ghana). 
may be required from a lawyer in the preliminary or incidental steps to any legal proceeding, arriving at or giving effect to a compromise in order to avoid or bring an end to any proceedings. ${ }^{46}$

Before a person qualifies to receive legal aid services in Ghana, he or she must apply to the officers of the Scheme in the region in which he or she resides. ${ }^{47}$ After the application, a selection committee appointed under the Act will then determine the application. An applicant whose application is approved would be exempted from paying the statutory fees that would have been paid for filing court processes and the cost of preparing appeal records. ${ }^{48}$

Additionally, legal aid is provided under the Courts $\mathrm{Act}^{49}$ of Ghana. Under this Act, where there is a matter pending before the Supreme Court, Court of Appeal, and the High Court and the justices presiding over the case are of the opinion that it is desirable and in the interests of justice that the party should have legal aid and that that party is financially unable to obtain the services of a lawyer, the respective justice may assign a lawyer by way of legal aid to represent that party in the court proceedings. ${ }^{50}$

Legal aid, it must be added, is not only available in small claims. For instance, in a juvenile court, before the commencement of legal proceedings involving a juvenile, ${ }^{51}$ the Court is obliged to inform the juvenile in a language the juvenile understands that he or she has the right to legal aid. ${ }^{52}$

Further, whistle-blowers in Ghana are also entitled to legal aid services. This occurs when a whistle-blower complains to the Commission for Human Rights and Administrative Justice (CHRAJ) that he or she is being victimised or apprehends possible victimisation for being a whistle-blower. ${ }^{53}$ When making inquiry into such complaints and CHRAJ is of the opinion that the whistle-blower needs legal assistance, CHRAJ 'shall issue a certificate to the whistle-blower to obtain legal aid from the Legal Aid Board or another institution that the Commission may specify in the certificate'. ${ }^{54}$

Having dealt with the general background to litigation in Ghana, we will, in the next paragraphs, give an overview of civil procedures in Ghana. Particular reference with respect to small claims will be discussed in the following chapter.

\section{An Overview of Civil Procedure and Small Claims in Ghana}

\subsection{Philosophical Underpinnings of Civil Procedure in Ghana}

The Parliament of Ghana, being the primary law-making organ of Ghana, is vested with the power to enact laws in Ghana. However, the enactment of rules of court to govern the practice and procedures in the civil justice system of Ghana has been reserved for the Rules of Court Committee. ${ }^{55}$ The Constitution provides that '[t]he Rules of Court Committee shall, by constitutional instrument, make rules and regulations for regulating the practice and procedure of all courts in Ghana' ${ }^{56}$ However, since these rules are made by constitutional instruments, they remain delegated legislation and are amenable to parliamentary scrutiny. Indeed, the Constitution stipulates that:

Any Order, Rule or Regulation made by a person or authority under a power conferred by this Constitution or any other law shall -

(a) be laid before Parliament;

(b) be published in the Gazette on the day it is laid before Parliament; and

(c) come into force at the expiration of twenty-one sitting days after being so laid unless Parliament, before the expiration of the twenty-one days, annuls the Order, Rule or Regulation by the votes of not less than two thirds of all the members of Parliament. ${ }^{57}$

Compliance with the above procedures for the enactment of constitutional instruments cannot be taken lightly. Recently, the Supreme Court held that a failure to follow the strict procedures of laying a proposed constitutional instrument before Parliament for the constitutionally prescribed period of twenty-one days automatically renders the said delegated legislation incurably invalid. 58

However, once the rules of court are duly passed in compliance with the above procedures, the attitude of the court towards enforcing these rules is quite relaxed. In applying the rules of court, the courts generally consider the primary goals and philosophy behind the civil justice system as it pertains in Ghana. In Ghana, the goals of the civil justice system are succinctly embodied in the statement of philosophy underpinning the rules

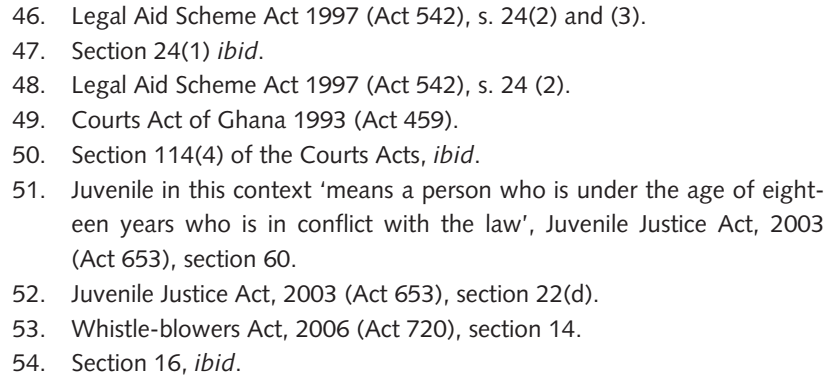

This decision of the Supreme Court has not been reported; available at <http://citifmonline.com/2015/02/27/supreme-court-cancels-districtassembly-elections/> (last visited 12 August 2016 at 15:25 GMT). 
of civil procedure as stated in the opening words of the High Court Civil Procedure Rules: ${ }^{59}$

These Rules shall be interpreted and applied so as to achieve speedy and effective justice, avoid delays and unnecessary expense, and ensure that as far as possible, all matters in dispute between parties may be completely, effectively and finally determined and multiplicity of proceedings concerning any of such matters avoided. ${ }^{60}$

The above provisions, together with a self-cleansing provision in the High Court Civil Procedure Rules, have gone a long way to ameliorate the reliance on undue technicalities and unreasonable insistence on form over substance that mostly frustrate the prosecution of claims before the courts. This 'self-cleansing' provision in the High Court Rules provides that:

Where, in beginning or purporting to begin any proceedings or at any stage in the course of or in connection with any proceedings, there has, by reason of anything done or left undone, been a failure to comply with the requirements of these Rules, whether in respect of time, place, manner, form or content or in any other respect, the failure shall not be treated as an irregularity and shall not nullify the proceedings, any step taken in the proceedings, or any document, judgment or order in it. ${ }^{61}$

216 It is noteworthy that the rules of court are quite liberal towards small and simple matters. Such matters are mainly dealt with by District Courts and Circuit Courts, as indicated earlier. For example, despite the civil justice system in Ghana being traditionally adversarial in character, the District Court Rules allow the court to assist a plaintiff to streamline his or her claim. The said rules provide that: 'Where it appears to the Court at the hearing of any action that the sum claimed in the particulars is less than the sum claimed on the writ, the Court may in the interest of justice amend the particulars to enable the plaintiff prove the claim as stated in the writ.' ${ }^{2}$

Further, in order to ensure that claims that appear before the courts are not unduly delayed by means of adjournments, and by extension increase the cost of

59. These Rules of Court are also applicable to the Circuit Courts, with the necessary modifications, Order 1 rule 1(1) of the High Court (Civil Procedure) Rules, 2004 ( $\mathrm{Cl}$ 47). The Rules of Court in Ghana are drafted by the Rules of Court Committee that is established under Art. 157 of the 1992 Constitution of Ghana. The power of this Committee, under Art. 157(2) of the Constitution, is that it shall 'by constitutional instrument make rules and regulations for regulating the practice and procedure of all the courts in Ghana'. Further, under section 28 of the Interpretation Act, 2009 (Act 792), the Rules of Court Committee is empowered to make rules that will regulate the practice and procedure of courts or tribunals in the exercise of any jurisdiction conferred on the courts by any enactment.

60. High Court (Civil Procedure) Rules 2004 (C.I. 47), Order 1 rule 1(2). The above provisions have been replicated in Order 1 rule $1(2)(a)$ to (d) of the District Court Rules, 2009 (C.I. 59).

61. High Court (Civil Procedure) Rules, 2004 (C.I. 47), order 81 rule 1(1).

62. District Court Rules, 2009 (C.I. 59), Ord 3 r 2(2). prosecuting claims, the Rules of Court generally frown on unnecessary adjournments and delays. In this regard, the High Court Rules and the District Court Rules, respectively, provide that: 'It is the duty of the parties, their lawyers and the Court to avoid all unnecessary adjournments and other delays, and ensure that causes or matters are disposed of as speedily as the justice of the case permits. ${ }^{63}$

It can be deduced from the above provisions that the drafters of the rules of court in Ghana did not intend the rules to be seen as intractable principles that must be followed sheepishly. The policy rationale behind the saving provisions in the rules of court can be gleaned from the authoritative dictum of Sophia Akuffo JSC thus: '... civil procedure [rules] act as [a] vehicle for actualization of substantive law and this has been likened to a handmaid rather than a mistress which must not be applied in such a hard and fast manner as to cause injustice in any particular case...' ${ }^{64}$

Against this backdrop and in order to do justice in cases that appear before them, courts in Ghana have not hesitated in waiving some breaches of the rules of court. In the following paragraph, the instances that the courts have waived breaches of the rules of court will be discussed.

\subsection{Waiver of Irregularities in Civil Proceedings in Ghana}

The above provisions have been applied by the courts in a number of cases where the justice of the matter so required. For instance, in the case of Friesland Frico Domo alias Friesland Food BV v. Dachel Co Ltd, ${ }^{65}$ Sophia Adinyira JSC stated that: '... non-compliance with the rules of procedure shall not render any proceedings void but be regarded as a mere irregularity which might be allowed...'.

In the above case, the defendant contended that contrary to the rules of procedure that were in force at the time of the institution of the action, which provisions are similar to the current High Court Civil Procedure Rules, the Plaintiff failed to seek leave of the court before issuing a writ of summons, notice of which was served on the defendant in Holland. The defendant further contended that the plaintiff also failed to seek leave of the court before service the notice of the writ of summons outside of Ghana. In both the High Court and the Court of Appeal, the defendant lost. It further appealed to the Supreme Court.

The import of the argument of the defendant was that the Supreme Court should set aside all the processes and proceedings before the High Court on the ground that the plaintiff did not ask for permission from the High Court before issuing the writ of summons and serving notice thereof outside Ghana. This case com-

63. High Court (Civil Procedure) Rules, 2004 (C.I. 47), Order 37 rule 2 and Order 27 rule 1 of the District Court Rules, 2009 (C.I. 56).

64. Republic v. High Court, Koforidua; Ex parte Eastern Regional Development Corporation [2003-2004] SCGLR 21 at 47.

65. Friesland Frico Domo alias Friesland Food BV v. Dachel Co Ltd. [2012] 1 SCGLR 41. 
menced in May 1994 and the decision of the Supreme Court was delivered on 22 June 2011. If the writ of summons as well as all the processes and proceedings were set aside, it would have meant that whatever transpired in the courts from 1994 to 2011 would have been a nullity. The cost, man hours, and the time that were used in prosecuting that case would have gone down the drain. In order to forestall such unfortunate occurrence, the Supreme Court inter alia dismissed that ground of appeal.

Further, in the case of Republic v. High Court, Accra; Ex Parte Allgate Co. Ltd. ${ }^{66}$ (Amalgamated Bank Interested Party), which case formed the basis of the decision in the Dachel Co. Ltd. case above, the Supreme Court speaking through Dr. Date-Bah JSC made it explicitly clear of its strict stance on not entertaining unnecessary technicalities in civil litigation in Ghana. In the Ex Parte Allgate Co. Ltd., the plaintiff bank filed a motion on notice for summary judgment ${ }^{67}$ against the defendant on 6 December 2007. The defendant was served with the motion on Wednesday 12 December 2007. The plaintiff moved the application for summary judgment on 18 December 2007 and same was granted. The contention of the defendant was that under the relevant rules on summary judgment, there should be four (4) clear days interval between the date the motion was served on it and the date the motion was moved. ${ }^{68}$ As a result, because the motion was served on the defendant on Wednesday December 12, the four clear days (excluding Saturday and Sunday) was on December 18 so the motion for summary judgment should have been moved from 19 December 2007.

The Supreme Court dismissed the contention of the defendant. In what is perhaps the locus classicus on the philosophy underpinning the interpretation and application of rules of civil procedure in Ghana, Dr. DateBah JSC with whom the rest of the justices of the Supreme Court agreed summarised the position of the law in Ghana thus:

To summarize then, where there has been non-compliance with any of the rules contained in the High Court (Civil Procedure) Rules, 2004 (CI 47), such non-compliance is to be regarded as an irregularity that does not result in nullity, unless the non-compliance is also a breach of the Constitution, or of a statute other than the rules of court or the rules of natural justice or othermise goes to the jurisdiction. (Emphasis added)

This decision is binding on the High Court and the Circuit Courts in Ghana. By necessary implication and in

66. Republic v. High Court, Accra; Ex Parte Allgate Co. Ltd. (Amalgamated Bank Interested Party) [2007-2008] 2 SCGLR 1041.

67. Summary judgment is a faster means of obtaining a judgment on a claim upon the plaintiff proving to the court that the writ os summons and statement of claim have been served on the defendant but the 'defendant has no defence to a claim in the writ' or any part thereof. Order 14 rule 1 of C.I. 47.

68. Order 14 rule 2(3) of C.I. 47 provides that the application for summary judgment together with all exhibit 'shall be served on the defendant not less than four clear days' before the return date on the motion paper. terms of Order 1 rule 2(a) to (d) of the District Court Rules, ${ }^{69}$ this salutary dictum is applicable to the District Magistrate Courts. As a result, in all proceedings before the High Court, Circuit Court, and the District Magistrate Courts, a breach of the respective rules of that court will not nullify the proceedings, thereby increasing the cost of the party in default. In effect, the courts in Ghana are willing to overlook some irregularities in the best interests of justice. The courts in Ghana have now firmed up their stance to look at substance rather than form. The caveat however is that the breach of the rules of court or the default should not at the same time be 'a breach of the Constitution, or of a statute other than the rules of court or the rules of natural justice or otherwise goes to the jurisdiction' of the court as indicated in the Ex parte Allgate case, discussed earlier.

\subsection{Substantial Justice over Technicalities}

Walking hand in hand with the above dicta is the stance taken by the Supreme Court to the effect that courts in Ghana should now aim at attaining substantial justice in all cases pending before them. This concept has been touted as 'substance over form' or the principle of substantial justice. Thus in the case of The Republic v. High Court, Accra (Delta Foods Case), ${ }^{70}$ Acquah JSC (as he then was) quoted with approval the dictum of Kpegah J (as he then was) in the case of Kuma v. Bart-Plunge $e^{71}$ thus: ' $\ldots$ it is the duty of every court to ensure that in a given situation, justice is done. Technicalities must not be permitted to frustrate this primary and all important function of the court ...'?

Further, in the case of Halle $E$ Sons v. Bank of Ghana ${ }^{72}$ Sophia Adinyira JSC opined that: 'Our courts have now come so far that any wrong step taken in legal proceedings should not have the effect of nullifying the judgment or proceeding.'

An important observation that can be made from the above cases is that the courts in Ghana are not prepared to allow excessive legalistic technicalities to stand in the way of expeditious and substantial justice. Remarkably, the objective of ensuring speed and substantive justice is a cross-cutting doctrine at all levels of civil justice system in Ghana. Thus, the rules of District Court emphatically declare their objective in clear and unambiguous terms similar as that of the High Court (Civil Procedure) Rules stated above. ${ }^{73}$

It is quite evident from the above discussions that the Ghanaian civil justice system eschews barren technicalities and rather advances effective, speedy, and affordable justice. Indeed, it has been noted that the objective in CI 47 serves as a constant statutory reminder to judges and lawyers that effective justice has become the declared objective of adjudication and that effective application of the rules of procedure must depend on a

69. District Court Rules, 2009 (C.I. 59).

70. The Republic v. High Court, Accra (Delta Foods Case) [1998-99] SCGLR 595 at 611.

71. Kuma v. Bart-Plunge [1980-90] 1 GLR 112 at 128.

72. Halle \& Sons v. Bank of Ghana [2011] 1 SCGLR 378.

73. District Court Rules, 2009 (C.I. 59), Ord.1 r 1. 
full appreciation of the fundamental purpose and spirit of the rules. ${ }^{74}$ The express declaration of the overriding objective of the civil justice system in Ghana is a concrete manifestation of Justice Cardozo's observation that 'the law has outgrown its primitive foundation stage of formalism when the precise word was the sovereign talisman and every slip was fatal' ${ }^{75}$

Beyond the above stance taken by the courts to sacrifice unnecessary legalistic technicalities on the altar of substantial justice, the rules of court also make room for instances where delays in small claims are curtailed. The rules of court permit, where necessary, for a plaintiff to obtain judgment at the interlocutory stages of a case without waiting for a full trial. Some of these instances are discussed below.

\subsection{Default and Summary Judgments}

The degree to which civil justice may be easy to access depends largely upon how flexible compliance with the rules of court is. Typically, all actions or causes, apart from matrimonial matters, cases relating to electoral disputes, or cases that require that a party commences his or case by an originating notice of motion, are required to be commenced by the issuance of writ of summons. It is stated that 'subject to any existing enactment to the contrary all civil proceedings shall be commenced by the filing of a writ of summons'. ${ }^{76}$ A similar provision embodied in the C.I. 59 states that '... every suit shall be commenced by a writ of summons issued by the Registrar on oral or written application and filled out and signed or marked by the plaintiff. ${ }^{77}$ A writ of summon is accompanied by statement of claim (in the case of the High Court and Circuit Court) or particulars of claim (in the case of the District Court).

A defendant after being served with the writ of summons and accompanying statement of claim or particulars of claim, as the case may be, is required by the rules of court to file notice of entry of appearance within eight days. ${ }^{78}$ However, where a defendant fails to enter appearance, the plaintiff may apply for judgment in default of appearance. ${ }^{79}$ The plaintiff may also apply for a summary judgment. In the case of summary judgment, the plaintiff must satisfy the court that the defendant does not have any defence to the claim endorsed on his or her writ of summons or part thereof. $^{80}$ The plaintiff will have to demonstrate or prove this fact by reference to only the pleadings (i.e. statement of claim, statement of defence, and reply, if any) without the need to adduce evidence in a fullblown trial. This procedure is available in both the lower courts and the High Court. ${ }^{81}$ Furthermore, a party may apply for judgment where an opponent makes a

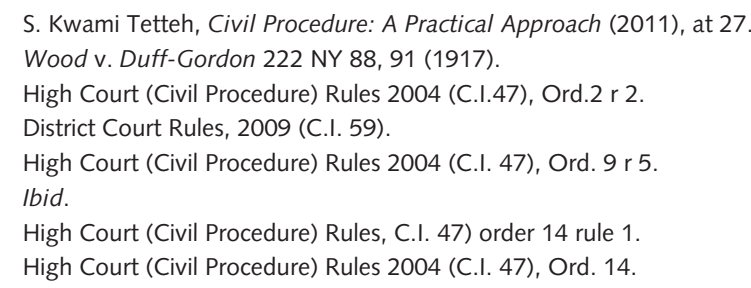

clear admission of the material facts in his or her claim. ${ }^{82}$ This obviates the necessity for a full trial.

Another simple procedure available in Ghana is the provision for undefended list in the District Court Rules. Thus, 'a plaintiff who wishes to place his [or her] suit on the undefended list, shall attach to the Writ of Summons an affidavit in support of the claim and all the documents which the plaintiff intends to rely on in support of the claim'. ${ }^{83}$ The condition precedent to placing the suit on the undefended list is that the writ should be one for the recovery of a debt or for a liquidated demand. Some decided cases have interpreted these conditions.

In the case of Fofie v. Pomaa, ${ }^{84}$ the High Court, considering provisions that are in pari materia with Order 8 of CI 59, held that a liquidated demand is in the nature of a debt, i.e. a specific sum of money due and payable under or by virtue of a contract. If the amount involved cannot be ascertained as a matter of arithmetic and rather requires investigation beyond mere calculation, even though it is specific or the sum named as definite figure, the sum is not a debt or a liquidated demand. The effect of successfully placing a suit on undefended list is that once there is proof of service and defendant is not able to put in an explanation before the court to suggest that he or she has a defence, then the plaintiff may be able to summarily obtain judgment against the defendant.

In an attempt to helping disputants to settle their disputes and differences amicably and on a win-win basis, Ghana, like many other countries in the world, is gradually moving towards other equally effective means of resolving disputes. In order to achieve this, many countries, including Ghana, have imbibed alternative dispute resolution regimes into the justice delivery system. The following paragraphs will be dedicated to the workings of alternative dispute resolution mechanisms in Ghana.

\section{Alternative Dispute Resolution in Ghana}

As was noted earlier, the adoption of a comprehensive legislation on alternative dispute resolution around the same period of the global financial crisis has created another opportunity in civil justice for small claims. The Alternative Dispute Resolution Act ${ }^{85}$ (hereinafter referred to as Act 798) was enacted to 'provide for the settlement of dispute by arbitration, mediation and customary arbitration...'. To achieve this, Act 798 identifies four broad methods of settling disputes including small claims. These are arbitration, mediation, negotiation, and customary arbitration. It has been argued that 'at the district court level (where most of the small claims are litigated), the methods of ADR most often encoun-

82. Ibid.

83. District Court Rules 2009 (C.I. 59), Order 8 r 1.

84. [1974] 2 GLR 6.

85. The Alternative Dispute Resolution Act, 2010 (Act 798). 
tered or employed in the settlement of disputes are negotiation, mediation and arbitration'. ${ }^{86}$ It is worthy of note that these ADR mechanisms were not dramatically novel in the sense that prior to adoption of this comprehensive legislation, Ghana had the Arbitration Ordinance (Cap. 16), the Arbitration (Foreign Awards) Ordinance (Cap. 17), and the Arbitration Act, 1961 (Act 38). What may be new is the bold attempt to codify principles of mediation extant in contractual practices. We will in the next paragraphs discuss these modes of ADR.

\subsection{Arbitration}

With regard to arbitration, Act 798 permits parties to an agreement to 'provide that a dispute arising under the agreement shall be resolved by arbitration'. ${ }^{87}$ Where there is such an arbitration clause in an agreement, no proceedings can be commenced in court until after the arbitration has been undertaken. This is because Act 798 permits a court to stay proceedings when a party commences a court action without first abiding by an arbitral clause. ${ }^{88}$

In the absence of an arbitral clause, a court can, with the consent of parties in writing, refer a matter pending before it for arbitration if the court 'is of the view that the action or part of the action can be resolved through arbitration' ${ }^{89}$ Also, if at any time before final judgment 'parties to an action desire that any matter in dispute between them in the action shall be referred to the final decision of an arbitrator, either party or both parties may apply to the Court at any time before final judgment for an order of reference' ${ }^{90}$ Coupled with these is the fact that courts and their officers have been admonished to 'promote reconciliation, encourage and facilitate the settlement of disputes in an amicable manner between and among persons over whom the court has jurisdiction'. ${ }^{91}$ With these provisions, courts are more likely to allow for an 'out-of-court' settlement of any civil case provided the parties are ad idem about the out-of-court settlement.

On the strength of the above provisions, parties to small claims proceedings may agree that their matter be settled by means of an arbitration. Adopting this procedure is rather inexpensive and not time consuming as compared with courtroom litigation. In any event, an arbitration award has the same effect as a judgment of a court. This is because by section 52 of Act 798, '... an arbitration award is final and binding between the parties and any person claiming through or under them'. Act 798 has also established the Alternative Dispute Resolution Centre, ${ }^{92}$ which, among other things, serves as a centre for the settlement of disputes through the various forms of dispute resolution mentioned above.

S.A. Brobbey, Practice and Procedure in the Trial Courts \& Tribunals of Ghana (2nd edn) (2011), at 515, para. 1141.

87. Section 2(1) of Act 798.

88. This is provided for under section 6 of Act 798.

89. Per section 7 of The Alternative Dispute Resolution Act, 2010 (Act 798).

90. High Court (Civil Procedure) Rules, 2004 (C.I. 47).

91. Courts Act, 1993 (Act 459), section 72(1).

92. Section 114 of Act 798 .

\subsection{Mediation}

With regard to mediation, the Act provides that 'a party to any agreement may with the consent of the other party submit any dispute arising out of that agreement to mediation by an institution or a person agreed on by the parties'. ${ }^{93}$ When a matter is pending before a court, either the court itself or any of the parties may refer the matter for mediations. In either case, the court is required to 'specify the time within which a report on the reference shall be submitted to the court'. ${ }^{94}$ The settlement reached by parties under a mediation process 'has the same effect as if it is an arbitral award'. ${ }^{95}$

It will be noted that the court cannot impose any of the forms of alternative dispute procedures on parties to a case before it. Where the court intends to refer a case pending before it to either an arbitration or mediation, the court must seek the consent of the parties. As a general rule, as has already been mentioned, courts in Ghana and their officers are expected to 'promote reconciliation, encourage and facilitate settlement of disputes on an amicable manner...' ${ }^{96}$ They are also expected to 'promote reconciliation among the parties, and encourage and facilitate the amicable settlement of the suit or proceeding'. ${ }^{97}$ The above policies point to the fact that the courts are supposed to play a facilitation role and not foist out-of-court settlement on parties. In this regard, opting for a quicker and less expensive yet very effective means of settling any dispute including small claims amicably is within the domain of the parties.

\subsection{Customary Arbitration}

As already indicated, the last form of the alternative dispute resolution mechanism is customary arbitration. Customary arbitration is said to be 'the process by which disputes are settled in accordance with customary law'. ${ }^{98}$ In Ghana, customary law is 'the rules of law, which by custom are applicable to particular communities in Ghana'. ${ }^{99}$ It is one of the primary sources of law in Ghana. ${ }^{100}$ Act 798 has codified the rules that govern customary arbitration in Ghana. The Act defines customary arbitration as 'the voluntary submission of a dispute, whether or not relating to a written agreement for a final binding determination by ... means of an impartial person appointed'. ${ }^{101}$ This method of dispute resolution is more frequently encountered in the District Court. This is because the District Court operates in a rather informal manner as compared with the other courts.

Brobbey JSC in the case of Boateng (No 2) v. Manu (No 2) ${ }^{102}$ held that a customary arbitration 'is binding if (a) the submission of the dispute to the customary arbi-

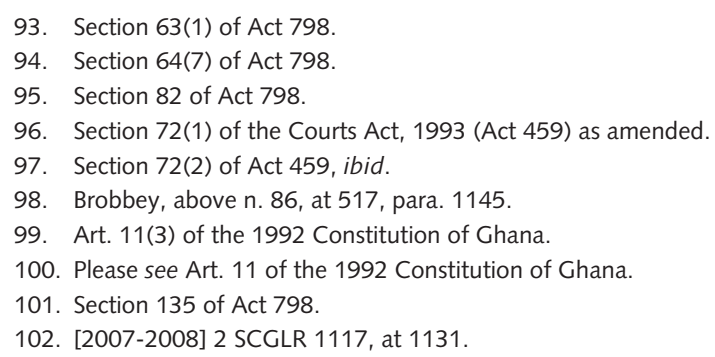


tration was voluntary; (b) the parties agreed to be bound by the decision whichever way it went; (c) the rules of natural justice were observed, although the arbitrator did not need to follow any formal procedures; (d) the arbitrator acted within jurisdiction; and (e) the decision or award was made public'. When all these requirements are met, then the customary award 'is binding between the parties and a person claiming through and under them'. ${ }^{103}$ A party to this award is not required to register it before it is enforced. However, a party is permitted to register the award either at the 'District Court, Circuit Court, or the High Court as appropriate'104 for purpose of enforcement. In such a case, the ward will have to be in writing. ${ }^{105}$

\subsection{Duty on the Courts to Adopt the Terms of Settlement Reached by the Parties}

It is worthy of note that in Ghana, once a case is settled by any of the out-of-court settlement processes discussed above, the courts are bereft of any power to interfere with the award, agreement, or terms of settlement that the parties will come out with. The only jurisdiction that the court has in those instances is to simply adopt the terms of settlement a consent judgment. In a case that was decided by the Supreme Court of Ghana in January 2015, the Court speaking through Gbedebge JSC held in the case of Republic v. High Court, Accra; Ex Parte Foseph Danso and 6 others, ${ }^{106}$ that:

According to the settled Court practice... the presiding judge does not interfere with the [settlement or] agreement and or compromise reached by the litigants and, rather, only sanctions it once it is within the law and does not raise any issue of illegality such as placing an obligation on a party to undertake an act; that is prohibited by law.

Prior to this decision, the Supreme Court in July 2014, speaking through Atugubah JSC held, in the case of Republic v. High Court, Accra (Fast Track Division); Ex Parte Debora Atakora, ${ }^{107}$ that:

The parties' terms of settlement (filed before the court after an out-of-court settlement) are binding on them because they are contractual... By allowing (a party) to overthrow that term, the trial court in effect granted him a dispensation to break his own contract arbitrarily. A court has no such jurisdiction.

By these cases therefore, the outcomes of out-of-court settlements are automatically binding. The courts are required to give their judicial blessings on them. ADR, like any human venture, has its ups and downs. In the following paragraphs, the benefits and challenges of ADR will be discussed.

\subsection{Benefits and Challenges of the Use of ADR Mechanisms in Resolving Small Claims in Ghana}

The various ADR methods that have been incorporated in the justice delivery system in Ghana have many benefits as far as small claims are concerned. There is no recorded empirical investigation to assess the effectiveness of the various procedures. Future empirical investigation into some of these matters will assist in illuminating us as to the actual impact of these ADR methods from users' perspectives. Literature on civil procedure in Ghana mainly engages in doctrinal analysis rather than sociolegal investigation.

Be that as it may, the fact that parties to a dispute who have not previously agreed upon ADR method for resolving their disputes can actually opt for that promotes access to justice and effective remedies at cheaper cost. Indeed, users of ADR methods including customary arbitration, negotiation, or mediation may avoid the considerable expense, as there is no requirement for legal representation. There are flexible time limits and there is no requirement for written pleadings as conditions precedent for prosecuting a case or defence.

Despite the foregoing merits of the various ADR methods, claimants are often dissatisfied when it comes to execution or enforcement of judgment or settlement entered by the court as judgment. The dissatisfaction is far worse for those who have obtained judgment for payment of money as in debt recovery cases. For a long time, the District Court had a procedure known as summons to show cause (equivalent of contempt of court). This procedure permitted the imprisonment of a judgment debtor who does not pay his debts. The Supreme Court however abolished this process sometime in 2007 when it held that no person could be imprisoned for non-payment of a judgment debt. ${ }^{108}$ Imprisonment for non-payment of debt was found to be inconsistent with the human rights regime of the 1992 Constitution. Indeed, prior to the 2007 definitive decision of the Supreme Court, the Court had signalled its intention in Republic v. High Court, Accra; Ex parte Laryea Mensah where the court explained contempt of court as follows:

By definition, a person commits contempt and may be committed to prison for wilfully disobeying an order of court requiring him to do any act other than the payment of money or abstain from doing some act; and the order sought to be enforced should be unambiguous and must be clearly understood by the parties concerned. ${ }^{109}$ [2015] 1 GHSCLR 71 at 75.

107. Republic v. High Court, Accra (Fast Track Division); Ex Parte Debora Atakora, unreported decision of the Supreme Court of Ghana, Civil Motion No. J5/27/2014 dated 22 July 2015.

108. The Republic v. High Court (Fast Track Division), Accra, Ex Parte P.P.E. Ltd and Paul Jurk (Unique Trust Financial Services Ltd) Interested Party (2007-2008) SCGLR 188.

109. Republic v. High Court, Accra; Ex parte Laryea Mensah [1998-1999] SCGLR 360, at 368. 
Prior to this judgment of the Supreme Court, winning party on threatening the losing party with imprisonment, the former was in most cases able to get the fruit of his or her judgment. However, as it stands now, even after settlement, a party may still have to go through court processes in order to be able to enforce the settlement that the parties might have reached. This obviously may be stressful to a party who settles a case out of court.

Although the decision in Ex parte Laryea Mensah advances the libertarian philosophy of Ghana's constitutional order, the fact still remains that it complicates execution of judgment. Indeed, the conundrum of execution of judgment is exacerbated by the absence of database on residential addresses and other vital particulars of citizenry that may be relevant in endeavouring to locate the assets or bank details of judgment debtors in order to levy execution.

\section{Assessing the Impact of Ghana's Economic Downturn on Civil Justice}

The global economic crisis made significant impact on Ghana's economy. It is instructive to note that the Government of Ghana ('GoG') in its budget statement to Parliament in 2009 emphatically pointed out that:

[t]he world economy witnessed three major shocks between 2007 and 2008: a global financial crisis, and upward spiral in food and fuel prices. These shocks have led to decreases in business investments and in consumer confidence, especially in the developed economies. For these reasons, the world economy turned sharply into a downturn in $2008 .^{110}$

The GoG in the same budget anticipated the inevitable consequences of the deteriorating global situation on the domestic economy. Thus, the Finance Minister acknowledged that:

Madam Speaker, the Global Financial Crisis (GFC) and the Credit Crunch (CC) are expected to impact on the Ghanaian economy in a number of ways. These include a reduction in external financing, remittances and export earnings, with adverse implications for the country's external reserves. ${ }^{111}$

The economic bleak at the global level continued to cast a shadow on GoG for a considerable period of time. In 2010, for example, the preoccupation of the government in its fiscal policy was 'how to shield social services from

110. K. Duffour, The 2009 Budget Statement and Economic Policies of the Government, <www.mofep.gov.gh/sites/default/files/budget/2009_ budget.pdf> (last visited 10 July 2015).

111. Ibid expenditure cuts'.112 Further into 2013, the global financial crisis was still having a domino effect on fiscal policy formulation in even developing countries. In this regard, GoG pointed out in its budget statement that '[i]n the advanced economies, growth slowed down from 1.6 percent in 2011 to 1.3 percent in 2012 , while in the emerging markets and developing economies, the spill over effects of the problems of the advanced economies combined with internal problems led to a reduction in growth rate from 6.3 percent in 2011 to 5.1 percent in 2012'. 113 The sub-Saharan Africa region was not shielded from the ferocity of the crisis as it also 'recorded slowdown in growth from 5.3 percent in 2011 to 4.8 in 2012'.

Another layer of complexity that beset Ghana was that around the same period of the global economic crunch, Ghana's economy had just attained the status of lower middle-income country. The GoG noted in the 2013 fiscal policy statement indicated that 'the downside of our transition to a Lower Middle Income Country (LMIC) status is that we shall gradually lose a substantial amount of grants and concessional loans that accrue to developing countries'. ${ }^{114}$ Unsurprisingly, GoG's 2012 projected budgetary revenue experienced 'a shortfall in grants from Ghana's development partners - GHф389.4 million ( 0.5 percent of GDP)'. ${ }^{115}$

Despite the fact that Ghana did not directly experience financial crisis to the same extent as the developed countries, it had its fair share of the wind of austerity measures that swept across the global economy. The indirect effect of the crisis on Ghana and in particular its civil justice has been quite spectacular. Firstly, there has been astronomical increase in the statutory fees that litigants are required to pay before filing court processes. ${ }^{116}$ For example, before the new Constitutional Instrument was promulgated, a litigant had to pay twenty-five Ghana cedis (GHc25) as a fee for filing notice of appeal against a final judgment or decision but now a litigant is required to pay as high as one hundred Ghana cedis (GHc100). This represents four hundred percent increase. While it cannot be posited categorically that the global economic crunch was the sole cause of the rise in the court filing fees, its contributory role in the increment in those fees cannot be ignored

In a country where there has not been a corresponding rise in incomes, a huge jump in fees would obviously be a burden on the citizenry and may effectively impede access to civil justice for many indigent litigants. The unprecedented sudden increase in the filing fees attracted overwhelming criticisms from legal practitioners and

112. K. Duffour, The 2010 Budget Statement and Economic Policies of the Government, para 40. <www.mofep.gov.gh/sites/default/files/budget/ Budget_2010.pdf> (last visited 20 July 2015).

113. S. Tekper, 'Sustaining Confidence in the Future of the Ghanaian Economy' (2013), para. 31. <www.mofep.gov.gh/sites/default/files/budget/ 2013_Budget_Speech.pdf> (last visited 21 July 2015).

114. Ibid., para. 16.

115. Ibid., para. 24.

116. The increase in the statutory filing fees came into effect after the promulgation of the Civil Proceedings (Fees and Allowances) (Amendment) Rules, 2013 (C.I. 81). 
the general public who lamented that justice was being put beyond the reach of the poor. ${ }^{117}$ One commentator bemoaned the increment as insensitive to the plight of already overburdened Ghanaians and remarked: '[t]he God fearing old judicial system created legal aid to offer free legal services to the advantage of the poor, but today, the suppression of increment will strengthen the hands of cheats and rich people against the poor which is an unfortunate situation'. ${ }^{118}$ The Rules of Court Committee that is mandated by the Constitution to make provision for court fees among others in reaction to the public outcry cited inadequate subvention from the government as making it necessary for the judiciary to raise additional funds through court filing fees. ${ }^{119}$ This huge rise in filing fees ought to have been gradual or preceded by adequate public consultation.

An additional impact of the financial crisis in Ghana is the unexpected reduction in the scale of operations of the judiciary. A key example here is that sometime in June 2014, the panels of the justices that sat at the Court of Appeal in the Kumasi and Cape Coast had to suspend their sittings in those regions because of lack of funds. ${ }^{120}$ Consequently, litigants in the northern sector Ghana were compelled to file their appeals in Accra and have it heard there as well. This inarguably worsened the financial predicament of such litigants. Thus, a litigant based in Tamale, Northern Ghana, who is aggrieved by the judgment or ruling by a trial court would have to travel 606 kilometres before he or she can appeal against the judgment or ruling. At the time of writing this article, the Court of Appeal, Kumasi, Cape Coast, and Tamale hold court sessions four (4) days every other month due to lack of funds. Apart the quantum of the cases that the justices have to handle, there is inordinate stress on litigants and lawyers, some of whom have to be in court from about 9 am to $5 \mathrm{pm}$ before they are given a hearing. This is because the litigants and their lawyers do not often know the precise time their cases will be called. Most of the air conditioners are not working in the courtrooms and coupled with the fact that the courtrooms are not spacious and well ventilated; conducting cases in those courtrooms is anything but conducive and serene. Lack of money in Ghana is actually affecting the quality of justice delivery in Ghana.

The costs of litigation coupled with travel and other inconveniences will ultimately make access to civil justice at the appellate level very expensive and implicitly deprive those in the low-income bracket as well as many small claims litigants access to justice. This is particularly important since access to justice should necessarily include the right to pursue one's claim across the full

117. J.A. Quarshie, 'Justice Now for Sale in Ghana?', available at <http:// newsghana.com.gh/justice-now-for-sale-in-ghana/> (last visited 5 June 2015).

118. Ibid.

119. Justice Dennis Adjei was quoted by TV3 Network 'Judicial service justifies increased legal fees', <http://ghanaculturepolitics.com/judicialservice-justifies-increased-legal-fees/> (last visited 6 June 2015).

120. Issah Alhassan, 'Kumasi Court Shut Down... After Cape Coast', available at <http://thechronicle.com.gh/kumasi-court-shut-down-after-cape -coast/> (last visited 18 November 2015). gamut of the justice machinery and not only at court of first instance.

The financial crunch and its concomitant austerity measures have shaped behaviour of users of the civil justice system. A case in point is where litigants seek the guidance of court clerks, court bailiffs, and commissioners of oath to draft their legal processes for them which eventually negatively affect the version of their case because of the possible legal lapses in those processes. Besides, litigants who engage the services of professional lawyers usually struggle to pay their legal fees and other incidental expenses.

In the face of the financial costs associated with litigation on both the side of the government and parties, there has been ongoing strong advocacy by the Judicial Service of Ghana for litigants and their lawyers to turn their attention the various ADR mechanisms for resolving their disputes instead of the traditional mode of courtroom litigation. One of the key reasons for this advocacy is that litigation is both costly in time and money to both the government and litigants alike. In commercial matters, for instance, Order 58 of the High Court Civil Procedure Rules, 2014 (C.I 47), makes it compulsory for litigants to attend a pre-trial settlement conference for a possible out-of-court settlement. At the pre-trial settlement conference, the judge supervises and guides the parties and their lawyers to mediate the dispute within thirty days. ${ }^{121}$ When the parties are able to resolve their dispute either before the pre-trial judge or by an external person or body, the parties will reduce the terms of the settlement into writing. These written terms shall then be read over and interpreted to the parties who will then sign the terms of settlement and same will be entered as consent judgment. ${ }^{122}$ It is only after settlement has broken down at the pre-trial settlement conference stage that the matter will be referred for trial. ${ }^{123}$

Undeniably, costs in terms of money and time are reduced if the settlement is successful and businesses are also spared the unnecessary stresses that come along with litigation. It is significant to note that in its 2014 Budget Statement, the GoG underscored the heavy reliance on cost-saving mechanisms for obtaining civil justice. The Finance Minister stated that:

Under the Legal Aid Scheme, 8,000 cases were handled through the provision of Alternative Dispute Resolution. In order to break the physical, economic and social barriers in accessing justice, the Legal Aid Scheme will strengthen the implementation of the -

121. High Court (Civil Procedure) Rules, 2004 (C.I. 47), order 58 rule 4(2). The thirty days notwithstanding, where after the thirty (30) days there is a reasonable prospect of settlement, then with the consent of the parties, the court can, in terms of Order 58 rule 5, extend the pre-trial settlement conference for another thirty (30) days.

122. Order 58 rule 7 , ibid.

123. Order 58 rule 8 , ibid. 
Justice For All programme with the introduction of weekend courts and small claims courts. ${ }^{124}$

From the discussion above, it can be deduced that litigation is having a heavy financial toll on the GoG and parties alike. This is having serious adverse effect on the justice delivery system in Ghana. The astronomical increase in filing fees, the rising cost of hiring lawyers, and irregularity with which the Court of Appeal, Kumasi, Cape Coast, and Tamale, sits are ample evidence of bad omen for small claims litigants in Ghana. To ameliorate the chilling effects of the challenges outline above, some recommendations that may go along to addressing the challenges have been discussed below.

\section{Recommendations for Improving Civil Justice Procedure for Small Claims in Ghana}

Undoubtedly, the direct and indirect effects of the global financial crisis in recent times have been quite noticeable in diverse ways as demonstrated above. Although one cannot predict with certainty as to whether the age of austerity will never recur in future, it would be prudent for necessary reforms to be introduced to enable civil justice systems for small claims to withstand any shocks and reverberations that resulted from the crisis. Towards this goal, we make the following recommendations.

In the first place, it is recommended that GoG intensifies public education concerning the numerous opportunities that have been introduced by the Alternative Dispute Resolution Act. This will empower parties to disputes to make use of the ADR mechanisms. It is gratifying to note that the GoG has committed itself in times past to 'provide adequate support for further propagation of the Principles of Alternate Dispute Resolution (ADR)'. ${ }^{125}$ A development worthy of commendation is the fact that in order 'to reduce congestion and long litigation in courts, the Judicial Service in 2014 referred 7,016 cases to ADR against a target of 10,000 ' ${ }^{126}$ Moreover, the ADR also 'mediated a total of 5,924 cases, out of which 4,181 of those cases were settled against an overall target of 7,000 cases'. ${ }^{127}$

Secondly, the financial allocation that is earmarked for the Legal Aid Scheme needs to be increased so that the

124. Seth Terkper, 'The 2014 Budget Statement and Economic Policies of the Government', para. 771. <www.mofep.gov.gh/sites/default/files/ budget/2014_Budget_Statement_0.pdf> (last visited 3 August 2015).

125. K. Duffour, 'The 2010 Budget Statement and Economic Policies of the Government', para. 806, <www.mofep.gov.gh/sites/default/files/ budget/2011_Budget.pdf> (last visited 16 July 2015).

126. Seth Terkper, 'The 2015 Budget Statement and Economic Policies of the Government', para. 707, <www.mofep.gov.gh/sites/default/files/ 127. Ibid scheme can employ or engage more lawyers to provide services for the ever-increasing clients of the Scheme. In view of government's budget constraints, it is further recommended that clinical legal education should be incorporated into the curriculum of all law faculties in the public universities in Ghana. ${ }^{128}$ While serving as a module for students to accumulate credit towards their LLB degree, they will also be acquiring essential skills as they work under supervision on real live cases. It will not be out of place for the government to introduce legislative reform to officially grant some level of audience to law clinic students in the District Courts where a lot of small claim cases are handled at the first instance. This recommendation coupled with GoG assurance to encourage radio and TV talk shows on legal aid especially on rights of the vulnerable and the need for lawyers to do pro bono. As an incentive for participating in pro bono legal aid schemes, the government may explore tax benefit for lawyers who take up pro bono briefs. ${ }^{129}$

Thirdly, we will recommend that the focus of legal education in Ghana should be redirected. Legal education in Ghana concentrates more on developing the adversarial skills of the law student. To this end, most lawyers in Ghana see litigation as a means to an end. As a result, little or no attention is given to alternative dispute resolution. Litigants are therefore left with no option but to spend years in court at huge expense to fight their cases. Fourthly, in order to reduce the unapproved expenses that litigants incur in their quest to seek justice, the Judicial Service of Ghana ought to do an in-house cleaning exercise. There are a lot of complaints by litigants about unapproved fees that they pay to court officials before they get basic things like service of documents that they have paid to file. The endemic corruption in the judiciary has also contributed to astronomical cost of litigation in Ghana. The nexus between judicial corruption and justice delivery has been amply noted in the literature. ${ }^{130}$ Pepys has stressed that 'until corruption within the judicial sector is severely controlled or eradicated, most legal and programmatic mechanisms put forth to reduce corruption in other sectors of society will be significantly undermined'. ${ }^{131}$

Consequently, we further recommend that Ghana intensifies its anti-corruption crusade in the judiciary and dispensation of justice generally. In this regard, the recent attempt of undercover investigation into collection of bribes by some magistrates and judges in Ghana

128. The Faculty of Law at Kwame Nkrumah University of Science and Technology, Kumasi in Ghana, is to be commended for introducing and running a module known as 'Law Clinic and Mooting' for the past four years.

129. K. Duffour, The 2010 Budget Statement and Economic Policies of the Government, para. 806, <www.mofep.gov.gh/sites/default/files/ budget/2011_Budget.pdf> (last visited 16 July 2015).

130. M.N. Pepys, 'Corruption in the Justice System', Sectoral Perspectives on Corruption (MSI- USAID, January 2003); B. Baker and E. Scheye, 'Multi-Layered Justice and Security Delivery in Post-Conflict and Fragile States', 7(4) Conflict, Security \& Development 503 (2007).

131. M.N. Pepys, 'Corruption in the Justice System', Sectoral Perspectives on Corruption 3 (MSI-USAID, January 2003). 
by a private investigation firm, Tiger Eye PI, ${ }^{132}$ is to be commended. This undercover video recording report has triggered far sweeping disciplinary proceedings against over fifty judges and magistrates. ${ }^{133} \mathrm{We}$ concede that the government itself is not free from corruption allegations and this may undermine its commitment and effectiveness towards combating judicial corruption. Nevertheless, it is our contention that efforts like the recent video report by Tiger Eye PI, collected over a year and half, can be openly published for consumption of the general public. It is a cliché that a well-informed public is better empowered to demand social accountability from the government. Public opinion will eventually mount pressure on the government to take necessary measures to address exposed corrupt judicial staff, magistrates, and judges.

\section{Conclusion}

The article has considered many salient issues emanating from the incidence of the economic hardships and access to justice for persons with small claims. It has been demonstrated that the global financial crises adversely affected Ghana's economy, notwithstanding the fact that almost around the same austerity era, Ghana's economic status had changed from developing country to lower middle-income country. Official government data has been deployed to buttress this point. 224 Excessive court filing fees, backlog of cases, and inability to engage services of lawyers were identified as some of the repercussions of the economic meltdown. To overcome the adverse effect of austerity measures on small claims, we have made some important recommendations including massive expansion of the legal aid scheme and introduction of clinical legal education. We have also recommended that there is need to refocus legal education in Ghana towards dispute resolution rather than the adversarial system. In order to cut down unnecessary expenses, we have also recommended that corruption should also be stamped out of the judicial system in Ghana.

132. <http://tigereyepi.org/> (last visited 23 November 2015).

133. A. Aremeyaw, 'How We Nabbed over 180 Corrupt Judges and Judicial Staff' - see more at <http://graphic.com.gh/features/features/49240how-we-nabbed-over-180-corrupt-judges-and-judicial-staff-anasaremeyaw.html\#sthash.HpQmiqqM.dpuf> (last visited 23 November 2015). 